\title{
PENGEMBANGAN LEMBAR KEGIATAN PESERTA DIDIK (LKPD) BERBASIS SCIENTIFIC APPROACH SISWA SMA KELAS X PADA MATERI FUNGI
}

\author{
Alvina Putri Purnama Sari \\ Agil Lepiyanto \\ Pendidikan Biologi \\ Universitas Muhammadiyah Metro \\ Alvinaevo99@gmail.com
}

\begin{abstract}
The objective of this research is to create the product of the Student Activity Sheet (LKPD) with scientific approach based. This research uses research procedure and development $4 D$ equipment model suggested by Thiagarajan, Semmel and Semmel. This model consist of 4 steps, they are Define, Design, Develop and Desseminate, however in this research and development, the activity is done only in to the development steps. The result of expert testing toward the design of come into being thes aspect of LKPD includes in the suitable criteria with the precentage 79,66\% and the result of the test in the material content of LKPD also includes suitable criteria with the precentage $81,22 \%$ and the last is the test of reading level LKPD by the students got very good criteria with presentage $80,3 \%$. Based on the result from expert testing and student testing, those show that LKPD scientific approach base has been developed properly to be used and ready to serve as one of the references in Biology learning material scientific approach based in Fungi.
\end{abstract}

Kata Kunci: lembar kegiatan peserta didik (LKPD), pendekatan saintifik.

Pendidikan merupakan salah satu hal yang harus dipenuhi oleh setiap manusia, dengan pendidikan kita mampu menjadi lebih baik dalam menghadapi permasalahan yang ada, termasuk semakin pesatnya perkembangan zaman. Pendidikan yang baik akan menghasilkan generasi yang baik pula, oleh sebab itu pemerintah selalu berupaya melakukan perbaikan-perbaikan mutu pendidikan. Perbaikan mutu pendidikan dengan harapan pendidikan di indonesia menjadi lebih baik, memiliki generasi penerus yang berkualitas. Pemerintah berupaya menerapkan pendidikan di indonesia dengan sebaikmungkin, salah satunya dengan pembelajaran yang berpijak pada pendekatan ilmiah. Permendikbud No. 65 tahun 2013 menjelaskan bahwa standar proses pendidikan dasar dan menengah telah dipandu untuk menerapkan pembelajaran dengan pendekatan ilmiah. Pendekatan ilmiah dapat diterapkan dalam berbagai aspek pendidikan, pendekatan ilmiah ini sudah lama diterapkan oleh pemerintah, hanya sajapelaksanaannya yang kurang maksimal. Salah satu penerapan pendekatan ilmiah dalampembelajaran yaitu dalam penyusunan bahan ajar. Bahan ajar yang disusun atau dikembangkan oleh guru berorientasi pada pendekatan ilmiah yang dapat menunjang perbaikan mutu generasi bangsa. Pengembangan berbagai bahan ajar saat ini telah banyak dilakukan oleh berbagai kalangan, baik guru ataupun percetakan buku untuk memenuhi kebutuhan pendidikan yang diharapkan 
pemerintah. Adapun hal tersebut juga dilakukan oleh peneliti untuk dapat mengembangkan Lembar Kegiatan Peserta Didik (LKPD) guna memenuhi kebutuhan pendidikan saat ini. LKPD ini pada dasarnya sama dengan LKS (Lembar Kegiatan Siswa) namun saat ini penggunaan istilah bahan ajar berbentuk lembar kegiatan ini menjadi LKPD. Sebelum melakukan pengembangan tahapan yang dilakukan yaitu observasi dan wawancara terhadap pihak sekolah SMA Muhammadiyah 1 Metro.

Berdasarkan hasil wawancara diketahui bahwa bahwa LKPD yang digunakan tersebut masih banyak komponen-komponen yang belum memenuhi kebutuhan sesuai kurikulum 2013. Setiap kegiatan belum mencerminkan proses pendekatan ilmiah yang saat ini sudah seharusnya diterapkan sesuai dengan kurikulum 2013, sekalipun ada kegiatan saintifik belum ditunjukkan secara maksimal. Melihat permasalahan di atas, maka peneliti bermaksud mengembangkan LKPD berbasis pendekatan ilmiah (scientific approach) guna memenuhi kebutuhan bahan ajar yang sesuai kurikulum 2013.

Menurut Sugiyono (dalam Beladina dan Kusni, 2013) Lembar Kegiatan Peserta Didik (LKPD) atau dalam kata lain Lembar Kerja Siswa (LKS) atau worksheet merupakan suatu media pembelajaran yang dapat digunakan untuk mendukung proses belajar. Siswa baik secara individual ataupun kelompok dapat membangun sendiri pengetahuan mereka dengan berbagai sumber belajar. Guru lebih berperan sebagai fasilitator, dan salah satu tugas guru adalah menyediakan perangkat pembelajaran (termasuk LKPD) yang sesuai dengan kebutuhan. Berdasarkan penjelasan yang disampaikan oleh Sugiyono, jelas bahwa pentingnya LKPD bagi siswa merupakan sebagai alat bantu untuk membangun pengetahuan mereka, dimana LKPD ini yang nantinya akan disiapkan oleh guru.

Trianto (2011) menyatakan bahwa LKS adalah panduan yang digunakan oleh peserta didik untuk melakukan penyelidikan ataupun mengembangkan kemampuan baik dari aspek kognitif atau yang lainnya. LKS memuat sekumpulan kegiatan yang harus dilakukan oleh siswa untuk memaksimalkan kemampuannya sesuai indikator yang sudah ditetapkan.

Sujarwanta (2012) menyatakan bahwa pembelajaran dengan menggunakan pendekatan saintifik adalah pembelajaran yang menekankan pada pemberian pengalaman secara langsung menggunakan observasi, eksperimen maupun cara yang lainnya, sehingga realitas yang akan berbicara sebagai informasi atau data yang diperoleh selain valid juga dapat dipertanggungjawabkan.

Permendikbud No. 65 tahun 2013 menjelaskan karakteristik kompetensi beserta perbedaan lintasan perolehan turut serta mempengaruhi karakteristik standar proses. Pendekatan saintifik dalam pembelajaran sebagaimana yang dimaksud meliputi mengamati, menanya, menalar, mencoba, dan membentuk jejaring untuk semua mata pelajaran.

\section{METODE}

Penelitian yang dilakukan yaitu penelitian pengembangan, adapun yang dikembangkan berupa bahan ajar Lembar Kegiatan Peserta Didik (LKPD). Prosedur yang dilakukan oleh peneliti dalam mengembangkan LKPD ini yaitu sesuai dengan model pengembangan 4D yang ditawarkan oleh Thiagarajan, Semmel, dan 
Semmel (dalam Trianto, 2011:93), adapun model pengembangan tersebut yaitu terdiri dari empat tahap pengembangan yaitu define, design, develop, dan desseminate. Dari keempat langkah pengembangan tersebut, dalam pengembangan LKPD berbasis pendekatan ilmiah ini terbatas sampai tahap pengembangannya saja, artinya langkah terakhir yaitu penyebaran tidak dilakukan oleh peneliti, hal ini karena adanya keterbatasan waktu dan biaya, sehingga pengembangan LKPD ini tidak sampai pada tahap penyebaran. Langkahlangkah mengembangkan LKPD ini yaitu

\section{Define/Pendefinisian}

Pada tahap ini yang dilakukan yaitu melakukan pra survey yang terdiri dari proses observasi dan wawancara, dengan melihat dan mencari kesenjangan yang ada di SMA Muhammadiyah 1 Metro. Permasalahannya yaitu tentang bahan ajar khususnya LKPD yang digunakan belum sesuai dengan kurikulum 2013 yang seharusnya sudah ada komponenkomponen kegiatan saitifik dalam setiap pembelajarannya.

\section{Design/Perancangan}

Pada tahap ini yang dilakukan peneliti yaitu menyiapkan atau membuat rancangan pengembangan LKPD yang akan dikembangkan. Kegiatan perancangan ini meliputi penyusunan format LKPD berbasis pendekatan ilmiah, perancangan LKPD ini bertujuan agar LKPD yang dihasilkan sesuai dengan yang dibutuhkan oleh peserta didik, baik dari segi penampilan, isi, format yang sistematis, dan sesuai dengan perkembangan kurikulum 2013 yaitu berbasis pendekatan ilmiah (scientific approach).

3. Develop/Pengembangan

Tahap pengembangan ini peneliti menghasilkan LKPD berbasis pendekatan ilmiah, yang sudah direvisi berdasarkan saran yang disampaikan oleh validator (dosen ahli), pengujian validasi ini akan dilakukan oleh ahli perangkat perangkat pembelajaran, dalam hal ini yaitu dosen Universitas Muhammadiyah Metro, dan selain itu guru mata pelajaran biologi SMA Muhammadiyah 1 Metro. Berikut skema pengembangan dan pengujian produk yang akan dilakukan, dalam Gambar 1.

Subjek coba dalam penelitian ini yaitu dosen, guru mata pelajaran biologi, dan peserta didik SMA Muhammadiyah 1 Metro. Penelitian ini menggunakan instrumen berupa angket yang berfungsi sebagai alat bantu pengambilan data, angket ini nantinya akan diisi oleh dosen dan guru mata pelajaran sebagai ahli, dan peserta didik.

Dalam penghitungan ini, menggunakan formula sebagai berikut

$$
\mathrm{P}(\mathrm{s})=\frac{S}{N} x 100 \%
$$

Keterangan:

$\mathrm{P}(\mathrm{s})=$ Persentase sub variabel

$\mathrm{S}=$ Jumlah skor tiap sub variabel

$\mathrm{N}=$ Jumlah skor maksimum

(Ali dalam Kristiningrum, 2007:40) 


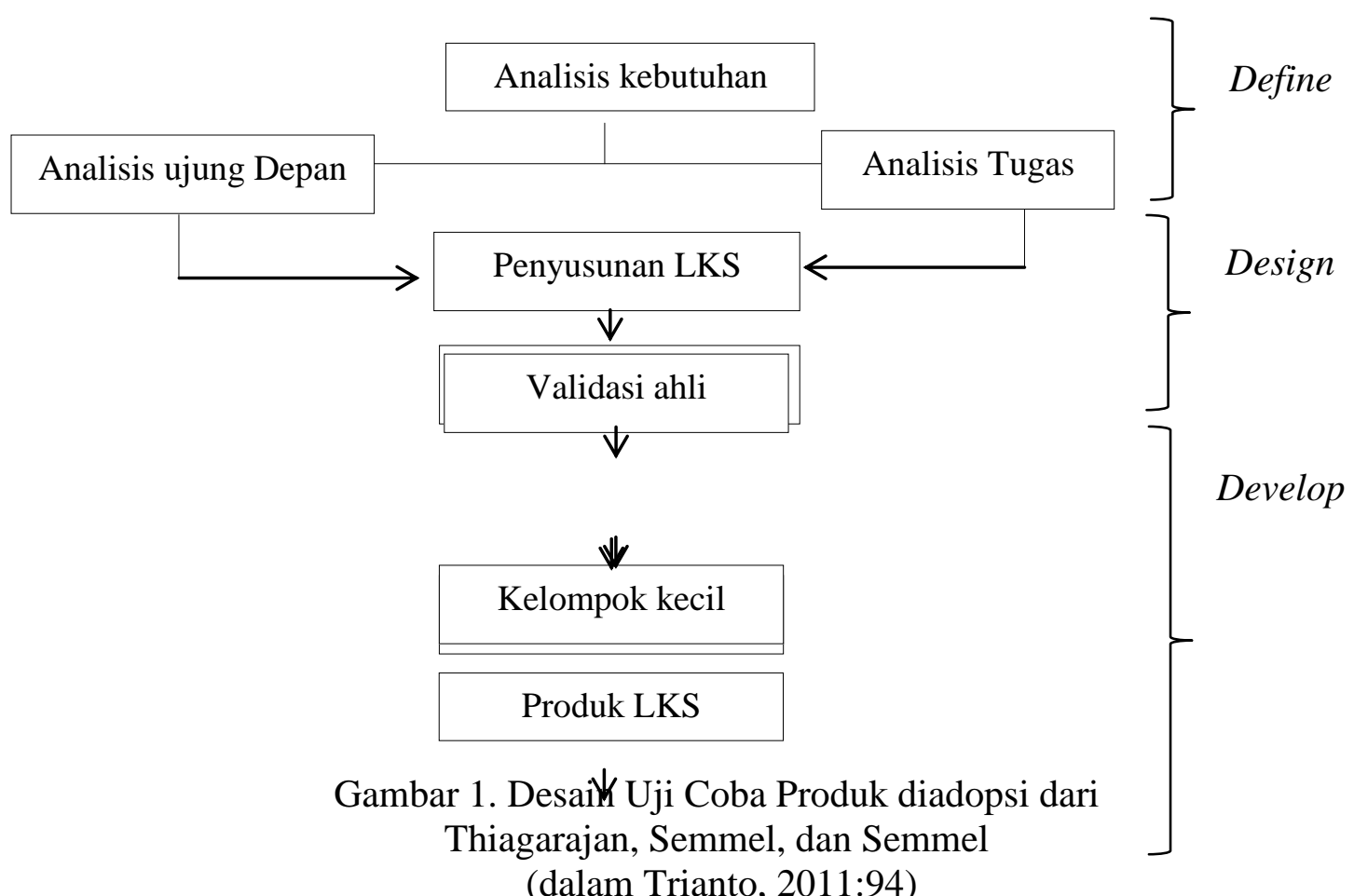

Tabel 1. Kriteria Persentase Angket

\begin{tabular}{l|l|l|l}
\hline No & $\begin{array}{c}\text { Interval rata-rata } \\
\text { penilaian ahli }(\%)\end{array}$ & Kriteria untuk ahli & \multicolumn{1}{|c}{$\begin{array}{c}\text { Kriteria untuk } \\
\text { peserta didik }\end{array}$} \\
\hline 1 & $80,01 \leq$ skor $\leq 100,00$ & Sangat Layak & Sangat Baik \\
\hline 2 & $60,01 \leq$ skor $\leq 80,00$ & Layak & Baik \\
\hline 3 & $40,01 \leq$ skor $\leq 60,00$ & Cukup Layak & Cukup Baik \\
\hline 4 & $20,01 \leq$ skor $\leq 40,00$ & Tidak Layak & Tidak Baik \\
\hline 5 & $0,00 \leq$ skor $\leq 20,00$ & Sangat Tidak Layak & $\begin{array}{l}\text { Sangat Tidak } \\
\text { Baik }\end{array}$ \\
\hline
\end{tabular}

\begin{tabular}{|c|c|}
\hline $\begin{array}{ccr}\text { Penafsiran ini } & \text { menggunakan } \\
\text { penafsiran } & \text { Ali } & \text { dalam }\end{array}$ & seperti paud 1 adel 1. \\
\hline $\begin{array}{l}\text { ristiningrum (2007:41), tafsiran ini } \\
\text { emiliki kriteria yaitu sangat layak, } \\
\text { yak, cukup layak, tidak layak, dan } \\
\text { Ingat tidak layak, selain itu penafsiran }\end{array}$ & $\begin{array}{l}\text { Penelitian ini dikatakan layak } \\
\text { digunakan jika persentase yang } \\
\text { diperoleh dari setiap penilaian oleh } \\
\text { responden berada pada rentang } 80,01 \leq\end{array}$ \\
\hline $\begin{array}{l}\text { Iri } \quad \text { kriteria } \\
\text { intepretasikan }\end{array}$ & $\begin{array}{l}\text { skor } \leq 100,00 \text { dan } 60,01 \leq \mathrm{sk} \\
80,00 \text {, dengan katagori atau kri }\end{array}$ \\
\hline
\end{tabular}
baik, baik, cukup baik, tidak baik, sangat tidak baik. Kriteria tersebut 


\section{HASIL}

1. Data Hasil Angket Pengujian Ahli dan Peserta Didik

Data hasil pengujian oleh ahli yaitu bertujuan untukmenilai tingkat kelayakan LKPD yang dikembangkan di nilai dari segi tampilan desai dan kelayakan isi. Masing-masing ahli media dan materi terdiri dari 3 orang ahli yaitu 2 dosen dan 1 orang guru. Pengujian oleh peserta didik yaitu memiliki tujuan untuk mengetahui tingkat keterbacaan LKPD yang telah dikembangkan, peserta didik yang menilai LKPD ini sebanyak 20 peserta didik.

\section{Analisis Data}

Berdasarkan pengujian oleh ahli dan peserta didik didapatkan hasil yaitu pengujian yang dilakukan oleh ahli media pembelajaran yang menilai kelayakan tampilan desain LKPD menunjukkan persentase penilaian sebesar 79,66\%. Pengujian oleh ahli materi yang menilai kelayakan materi dalam LKPD yang telah dikembangkan menunjukkan persentase penilaian sebesar $81,22 \%$. Kedua hasil pengujian oleh ahli tersebut menurut pendapat Ali dalam Kristiningrum (2007:41) masuk dalam kriteria "Layak" dan "Sangat Baik". Penilaian tersebut dapat disajikan dalam gambar 2 .

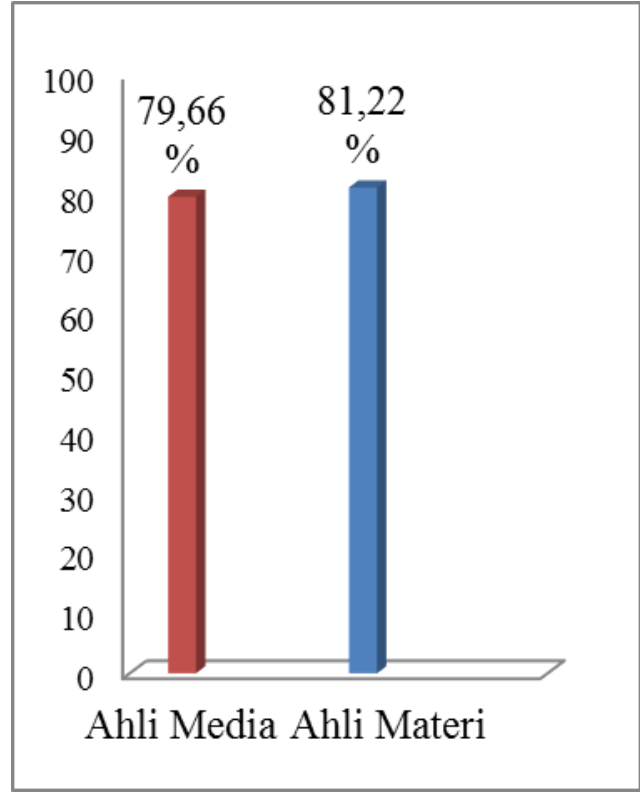

Gambar 2. Hasil Analisis Pengujian Ahli

Hasil analisis data oleh peserta didik menunjukkan secara keseluruhan LKPD yang telah dikembangkan sudah sangat baik untuk digunakan karena presentase yang diperoleh berdasarkan perhitungan data sebesar $80,3 \%$.

2. Revisi Produk

Hal-hal yang telah direvisi dari saran ahli dijelaskan sebagai berikut:

a. Ahli Media Pembelajaran

1) Fontasi diperjelas (Cover) tidak perlu diberi bayangan pada tulisan. Pewarnaan cover disesuaikan dan tidak perlu diberi nama penulis.

2) Peta konsep dibenahi, dibuat secara terperinci.

3) Alur bacaan LKS diperjelas, pada halaman 5 mohon diberikan tabel pengamatan.

4) Sumber referensi diberi tanda kurung.

5) Lembar pengamatan pada halaman 11 disesuaikan dengan peta konsep, dan nama jamur diletakkan di bawah.

6) Pembagian jamur pada halaman 6 diperbaiki lagi.

7) Menambahkan kata sumber pada setiap daftar referensi. 
b. Ahli Materi

1) Tambahkan KD 4.6 pada identitas LKPD.

2) Setiap kegiatan diberikan struktur pengerjaannya apakah secara individu atau berkelompok.

3) Kajian scientific approach khusus pada tahapan mencoba perlu dikaji lagi, tambahkan kegiatan lainnya.

Berdasarkan hasil rekapitulasi data yang telah dilakukan, LKPD sudah layak dan baik untuk digunakan, namun revisi produk tetap peneliti lakukan sesuai dengan saran atau masukan yang telah diberikan oleh para dosen ahli. Perbaikan ini dilakukan agar LKPD hasil pengembangan lebih layak dan lebih baik lagi untuk digunakan dalam proses pembelajaran. Hal-hal yang telah direvisi sesuai dengan saran atau masukan dari para ahli dijelaskan sebagai berikut:

1. Memperbaiki tampilan cover dengan tidak memberikan bayangan pada tulisan.

2. Memperbaiki penyusunan peta konsep. Peta konsep seharusnya disusun secara terperinci sehingga lebih memudahkan peserta didik dalam belajar. Pentingnya perbaikan peta konsep ini sesuai dengan peran dari peta konsep itu sendiri.

3. Memberikan tambahan indikator pada KD 4.6 pada identitas LKPD tentang keterampilan yang juga harus dimiliki oleh siswa. Sesuai hasil saran dosen ahli maka indikator pada KD 4.6 telah ditambahkan. Indikator perlu diperhatikan dalam melakukan pengembangan produk karena menurut Muljono (dalam Prasetyo, dkk. 2013:194) fokus validasi isi atau materi adalah mengukur konstruk atau komponen kelayakan isi, yaitu kelayakan isi LKS dengan SK dan KD mata pelajaran.

4. Memberikan tambahan kegiatan pada komponen mencoba pada LKPD. Penambahan kegiatan pada komponen mencoba telah diberikan oleh peneliti yaitu berupa kegiatan kunjungan lapangan ke tempat pembuatan tempe, dengan harapan peserta didik mengerti secara langsung proses pembuatan tempe dan mampu menceritakan kepada orang lain.

Pengembangan LKPD ini berbasis scientific approach, artinya dalam LKPD ini terdapat komponenkomponen scientific approach yaitu terdiri mengamati, bertanya, menalar, mencoba, dan membangun jejaring untuk semua mata pelajaran. Berdasarkan hasil yang diterima oleh peneliti terhadap LKPD yang dikembangkan yaitu bahwa LKPD yang dikembangkan sudah layak untuk digunakan sebagai salah satu referensi dalam proses pembelajaran di SMA kelas X khususnya pada materi fungi. Hal ini ditunjukkan dengan rekapitulasi data atau nilai yang diberikan oleh ahli media yaitu sebesar 79,66\%. Kelayakan materi yang di uji oleh ahli juga menunjukkan bahwa materi yang telah dikembangkan sudah layak untuk digunakan, dengan ditunjukkannya pemberian angka atau nilai sebesar $81,22 \%$, selain penilaian dari tim ahli LKPD yang telah dikembangakn ini juga sudah dikatakan baik untuk digunakan berdasarkan penilaian yang diberikan oleh peserta didik yang telah direkapitulasi dan memberikan hasil akhir sebesar 80,3\% sehingga LKPD ini sudah sangat baik untuk digunakan.

Bahan ajar yang dikembangkan oleh peneliti ini memliki kelebihan dan kelemahan, yaitu sebagai berikut: 
1. Kelebihan Produk Hasil Pengembangan

a. LKPD yang dikembangkan ini memuat komponen-komponen scientific approach yang mampu meningkatkan kemampuan siswa dalam proses pembelajaran.

b. LKPD yang dikembangkan ini dapat digunakan secara mandiri karena dilengkapi dengan petunjuk penggunaan dari setiap kegiatan.

c. Siswa dapat menggunakan LKPD ini dengan semangat karena tampilan dari LKPD yang menarik, dan tidak membosankan.

d. LKPD ini mampu meningkatkan daya berfikir siswa dengan adanya pertanyaan-pertanyaan yang harus diselesaikan dalam waktu yang telah ditentukan.

e. Berbagai kegiatan lapangan yang harus dikerjakan mampu meningkatkan keterampilan yang dimiliki oleh siswa.

f. Siswa dapat berfikir luas karena LKPD ini dilengkapi dengan soal-soal diskusi yang mengharuskan siswa mengkomunikasikan atau mencoba mengaitkan materi fungi dengan materi atau pelajaran yang lain.

2. Kelemahan Produk Hasil Pengembangan

a. LKPD yang dikembangakn masih kurang ringkas.

b. Bahan ajar yang dikembangkan terbatas hanya pada materi fungi.

c. Soal-soal dalam LKPD ini masih sedikit.

Berdasarkan hasil penelitian dapat diketahui bahwa LKPD hasil pengembangan ini sudah layak dan baik untuk digunakan. Peneliti menyarankan agar guru dapat memanfaatkan hasil pengembangan ini dalam kegiatan proses pembelajaran, guna menunjang kompetensi yang harus dimiliki siswa. Adapun kelemahan dalam LKPD ini nantinya bisa diperbaiki seiring berjalannya waktu. Penyebaran produk ini juga dapat dilakukan guna mendapatkan berbagai masukan, dan akan menjadi lebih baik lagi produk yang dihasilkan, dan dapat dimanfaatkan oleh peserta didik lainnya. Peneliti menyarankan ketika ingin mengembangkan suatu produk agar memperhatikan kembali tahapan yang harus dilakukan dalam penelitian pengembangan. Penelitian ini dapat dilanjutkan dengan mengujikan produk yang telah dikembangkan ke sekolah. Diharapkan dari hasil pengujian dapat diketahui seberapa besar peran LKPD ini dalam meningkatkan hasil belajar siswa khususnya pada materi fungi.

\section{DAFTAR PUSTAKA}

Beladina, Suyitno, dan Kusni. 2013. Keefektifan Model Pembelajaran Core Berbantuan LKPD terhadap Kreativitas Matematis Siswa. Unnes Journal of Matematics Education (UJME) 2 (3) (2013). FMIPA Universitas Negeri Semarang, Indonesia.

Kristiningrum. 2007. Pengembangan Multimedia Pembelajaran Interaktif dengan Macromedia Authowere 7.0 pada Materi Fisika Sekolah Menengah Atas (SMA) Pokok Bahasan Kinematika Gerak Lurus. Skripsi Tidak diterbitkan. Semarang: Unnes. 
Permendikbud No. 65. 2013. Standar Proses Pendidikan Dasar dan Menengah.Jakarta: Depdiknas.

Prasetyo, dkk. 2013. Pengembangan Lembar Kegiatan Siswa Bermuatan Karakter pada Submateri Filum Molusca Kelas X SMA. BioEdu. Vol.2 No. 3 Agustus 2013. Jurusan Biologi FMIPA Universitas Negeri Surabaya.

Sujarwanta, $\quad 2012$.

Mengkondisikan Pembelajaran IPA dengan Pendekatan Saintifik. Jurnal Nuansa Kependidikan Vol 16 Nomor 1, Nopember 2012.

Trianto. 2011. Model Pembelajaran

Terpadu. Jakarta: Bumi Aksara. 